\title{
The Populations and Habitat Preferences of Three Elm Species in Conditions Prevailing on Plains of Poland
}

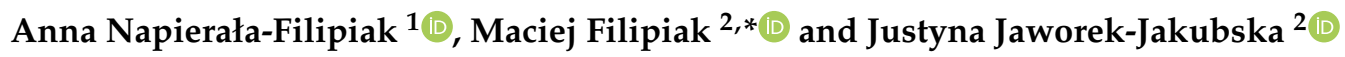 \\ 1 Institute of Dendrology, Polish Academy of Sciences, ul. Parkowa 5, 62-035 Kórnik, Poland; \\ annafil@man.poznan.pl \\ 2 The Faculty of Environmental Engineering and Geodesy, Institute of Landscape Architecture, \\ Wrocław University of Environmental and Life Sciences, ul. Grunwaldzka 55, 50-357 Wrocław, Poland; \\ justyna.jaworek@upwr.edu.pl \\ * Correspondence: maciej.filipiak@upwr.edu.pl; Tel.: +48-699-117-582
}

check for

updates

Citation: Napierała-Filipiak, A.; Filipiak, M.; Jaworek-Jakubska, J. The Populations and Habitat Preferences of Three Elm Species in Conditions Prevailing on Plains of Poland. Forests 2021, 12, 162. https://doi.org/ 10.3390/f12020162

Received: 24 October 2020

Accepted: 16 January 2021

Published: 30 January 2021

Publisher's Note: MDPI stays neutral with regard to jurisdictional claims in published maps and institutional affiliations.

Copyright: (C) 2021 by the authors. Licensee MDPI, Basel, Switzerland. This article is an open access article distributed under the terms and conditions of the Creative Commons Attribution (CC BY) license (https:// creativecommons.org/licenses/by/ $4.0 /)$.

\begin{abstract}
From among the 35-40 elm species existing around the world, three are native to Europe: the wych elm (Ulmus glabra Huds.), the European white elm, (Ulmus laevis Pall.), and the field elm (Ulmus minor Mill.). The populations of these trees have been greatly reduced as a result of a decrease in the total area of riparian forests. Furthermore, for nearly 100 years, they have been destroyed by Dutch elm disease (DED). The main research problems of this study are: what are the habitat preferences of elms growing in a given area; and whether the occurrence of DED depends on the species of elm and the habitat in which it occurs. The results presented here are based on field studies and observations have been supplemented with data from forest inventories. All of the examined elms are definitely more abundant in habitats that are fertile or very fertile and moist, with a neutral or slightly alkaline soil $\mathrm{pH}$. The preference for moist sites is the most evident in the case of $U$. laevis and the least evident in the case of U. glabra. A slight shift in habitat preferences of the field elm, compared to the white elm, towards less humid conditions was observed. The predominant species of elm in the studied area is currently $U$. laevis, which was rarely cultivated in forests in the past. In the examined area, the field elm population is clearly on the decline mainly due to the long-term presence of Dutch elm disease. U. glabra is the rarest species in the examined area and most often found on slopes. The current proportions of individual species should be maintained. This paper discusses factors, including ones not connected with DED, that may be responsible for the current state of populations of particular species of elm in forests of Central Europe.
\end{abstract}

Keywords: Ulmus glabra; Ulmus minor; Ulmus laevis; Dutch elm disease; alluvial forests; anthropopression

\section{Introduction}

The elm belongs to the Ulmaceae family. From among 35-40 elm species existing around the world, three are native to Europe: the wych elm (Ulmus glabra Huds.), the European white elm, also known as the fluttering elm, spreading elm or stately elm (Ulmus laevis Pall.), and the field elm (Ulmus minor Mill.), and their natural ranges include Poland [1]. All of the species listed above are first-size trees, i.e., ones that reach over $30 \mathrm{~m}$ in height in proper conditions (in Poland), and occur in the upper canopy layer [2].

The resources of these trees have been greatly reduced as a result of a decrease in the total area of riparian forests, and, for nearly 100 years, they have been destroyed by Dutch elm disease (DED) - a fungal pathogen that was-as quite commonly accepted -spread as a result of human activity [3-5].

Elms (Ulmus spp.) used to be abundant trees in many places throughout Europe, especially near rivers, streams, and flood plains. Since ancient times, the trees have been used by humans in various ways, and several selected genotypes, especially $U$. minor, has been propagated and disseminated on a massive scale [4,6]. Reputedly, the Polish name of elm derives from the compactness of its wood, which is exceptionally hard to split. Because 
of this characteristic, the wood was used to make spokes, and especially wheel hubs for carts and coaches. Because of its durability and resistance to water, it was also used to build bridges and water facilities. Thanks to considerable hardness and attractive patterns, it has always been highly valued as a furniture material. It was also used for making weapons (bows, gun carriages, and butts, as well as cannon carriages). Until recently, in many places of Europe and elsewhere, elms were often fed to animals and served as live supports for growing vines [2,7].

Dutch elm disease (DED) is one of the first examples of how introduction of foreign pathogens can globally threaten the ecological role and functions of key species in native forests [6]. The enormous disturbances caused by the DED pathogens have led to considerable economic losses and the abandonment of the use of the tree in forests or as a landscaping element. In Europe, the disease is caused by Ophiostoma ulmi Buisman and O. novo-ulm Brasier, and is spread by Scolytinae bark beetles. The relations between insects and O. ulmi s.l. depend on several factors, such as environmental conditions as well as interactions between biocenosis elements $[3,4,6,8-10]$. The impact of the domestication of elms on the outcome of the DED pandemic is difficult to evaluate, but the spread of the disease may have been accelerated in areas where elms had been introduced artificially [4]. DED is claimed to be one of the worst plant diseases ever [6]. Mackenthun [11] determined quantitatively elm losses and their causes on two flood plains in Saxony (Germany), and stated that human impact may be responsible for the destruction of $90 \%$ of the original elm habitats, while DED for another $90 \%$ of the remaining population. This is why today we can see just $1 \%$ of what used to be elm-dominated flood plains. All of the three native elm species in Poland are susceptible to infection with DED pathogens, but they show different degrees of damage $[4,9,12-14]$.

U. glabra (the wych elm) is the most abundant European elm in the north of Europe. It is adapted to the hemiboreal and temperate climates and thrives in moist forests with rich soils and high humidity as well as along streams, but not in soils that are frequently inundated or very moist. Usually, it is to be found in mixed deciduous forests, and in the southern area of its prevalence, it grows almost exclusively in mountain regions, where it is, therefore, referred to as the 'mountain elm' [4]. Studies of the Polish populations of the wych elm [15] have confirmed the results of earlier studies into the variability of the wych elm in Europe, showing that it is a species with a relatively low degree of genetic variability, but with a significant interpopulation variation. The Polish populations have a lower mean number of alleles in the locus $(A=6)$ than the Danish $(A=8)$ and Spanish $(\mathrm{A}=9)$ populations, and their expected heterozygosity $(\mathrm{He}=0.602)$ falls in between that of the Spanish populations $(\mathrm{He}=0.566)$ and the Danish populations $(\mathrm{He}=0.774)$. The Polish populations are much less diverse than the Spanish, Fst $=0.089$ and Fst $=0.239$, respectively $[16,17]$. In Poland, the wych elm is practically the only representative of the genus Ulmus at locations above 400 MASL [14].

Ulmus laevis (the European white elm) is a riparian tree, usually growing along major European rivers in Central and Eastern Europe. Small, fragmented populations of the species can also be found in Spain and southern France, along streams and rivers, as well as near seasonal swamps [18]. Genetic variability studies have shown that the Iberian Peninsula was probably the glacial stronghold for the species [19]. The species grows in moist, periodically flooded areas, preferring slightly acid and siliceous soils.

The third native elm, $U$. minor (the field elm), is more common in lower latitudes. Naturally, it grows near rivers and streams, and prefers calcareous soils. In such conditions, before the DED pandemic, it was often the predominating tree species in forests [11,20]. It also grew in areas away from river banks, as it is well adapted to tolerate poor soils with a certain level of water deficit in the summer [2,6], which allowed the tree to be commonly included in urban and extra-urban plantings $[2,6,21]$. Today, mature populations have practically disappeared from a majority of areas of previous natural occurrence $[4,6]$. The field elm populations in Poland are generally characterized by a low degree of genetic variability and a relatively high clonality. In Poland, the genetic variability of the field elm 
$(\mathrm{A}=7.0, \mathrm{Ae}=1.9, \mathrm{He}=0.383)$ is significantly lower than that of the mountain elm in Poland $(\mathrm{A}=13.2, \mathrm{Ae}=3.2, \mathrm{He}=602)[15]$.

European elms are considered as trees with valuable ecological properties and an important component of the ecosystem they are part of $[2,8,21]$. They co-exist in close relationships with a large number of organisms, from microorganisms to insects [21]. Within a small study area, Heybroek [22] recorded 79 species of insects clearly connected with elms, which indicates an important contribution of the tree to biological diversity. Representatives of the genus elm often display a considerable capability for adapting to various changes in the environmental conditions, which is likely to be connected with their substantial physiological plasticity [23-26]. In the dynamic classification [8], European elms are regarded as post-pioneers. In the natural forest regeneration process, i.e., natural succession, post-pioneers develop under the canopy of pioneers (in the case of lowland elms, they are usually poplars), and over time, they give way to 'driads,' but usually they do not disappear from the forest entirely, staying there as an admixture. Their falling leaves significantly speed up the tempo of the general forest cover decomposition and matter circulation in the ecosystem. Fallen elm leaves accelerate forest cover decomposition particularly well (e.g., [8,27-29]. In areas covered by riparian forests that accompany natural, unregulated major rivers, as a result of repeated destructive overflows, forest succession often stops at the stage of riparian post-pioneers-ashes and elms [2,30].

In most European countries, various steps are undertaken to protect and restitute elms. During the last 100 years, much effort has been made to understand the disease and the factors that affect it as well as to produce elm varieties resisting or tolerating the disease $[4,6,31,32]$. A majority of contemporary publications regarding elms in Europe indicate the need to increase the role of the species in the continent's general forest resources, also with the use of foreign and crossbreed species. On the other hand, it is pointed out that certain limitations should be imposed on human intervention in gene flows to what are likely natural populations. Observations conducted in France [4] indicated that it might be a good idea to examine the possible impact of Asian or crossbreed varieties on the native genetic resources, especially considering the fact that the flowering periods of the best-known resistant varieties: Lutece 'Nanguen' and 'Sapporo Autumn Gold' partly correspond to the flowering periods of the field elm, and seeds collected from these varieties have produced viable seedlings. The negative consequences of introducing foreign elms (hybridization and introgression between the exotic and the native elm,) especially the Siberian elm (U. pumila L.) in Italy, Spain, and the USA, are well documented [33].

For the last several years, we have been evaluating the elm resources in Poland. As a result of the work, the total number of elm localities has been determined (based on forest documentation) [12] and the number of individual species in forested areas has been estimated [14]. Nearly 800 localities have been directly described and characterized in various respects, including DED occurrence. Considerable amounts of information regarding the ecology of the studied trees, as well as the presence of DED and associated insects has been collected [13].

In comparison with other tree genera, there are few publications on Ulmus spp. Most of them concern various aspects more or less connected with the problem of the Dutch elm disease (DED) epidemic (e.g., [6,34-39]). Furthermore, there have been publications on ecophysiology, and recently, also genetics $[17,40,41]$. Most of contemporary publications regarding elms in Europe stress the need to investigate their ecology in more depth. Our studies have been following this suggestion.

The main research problems of this study are:

- The habitat preferences of elms growing in a given area.

- Whether the occurrence of DED depends on the species of elm and the habitat in which it occurs.

The main means of achieving this goal is by determining the frequency of localities of individual elm species in different types of habitats. These problems are related to the 
issue of individual European elm species' importance in today's forest communities and in the general population of the studied genus.

The whole is presented against the background of data characterizing the general (without division into species) population of elms. These data come from the analysis of forest documentation.

A new element of this study is also the use of two types of habitat classification: one made during field research and based on the topography of the area, and the other based on forest documentation and on soil classification.

These results are to be complemented by the characteristics of the general resources and habitat preferences of elm trees in the study area (without division into species) based on data from forest inventory (35,000 records).

The results of our research should be of cognitive and practical importance, e.g., for determining the forest stands composition.

\section{Materials and Methods}

\subsection{Study Area}

The data used in this paper come from a part of Poland located in four natural forest regions (III, IV, V, VI), i.e., large areas characterized by more or less uniform conditions for forest growth and forest production (Figure 1, Table 1). The above-mentioned natural forest regions are described in the publication referred to above [14]. The region of study was selected because of its relatively large area $\left(220,406 \mathrm{~km}^{2}\right)$ and the quantity of data available for analysis, as well as its significant representativeness. The study area is in the center of the natural range of all three studied elm [1,8]. It is also part of the North European Plain, which, apart from most of Poland, covers the northern part of Germany and the territory of Denmark, Belgium, and the Netherlands. In addition, it is part of the area of 'Mesophytic deciduous broad-leaved and mixed coniferous broad-leaved forests' - a plant formation extending from northern Spain to central Russia-and the area of occurrence of 'Central European hardwood alluvial forests' which are distributed from north-eastern France to Poland (in the north-east) and to Croatia in the south [42]. It follows that the study area is part of larger elm occurrence areas, and the results of our work should be relevant to them as well.

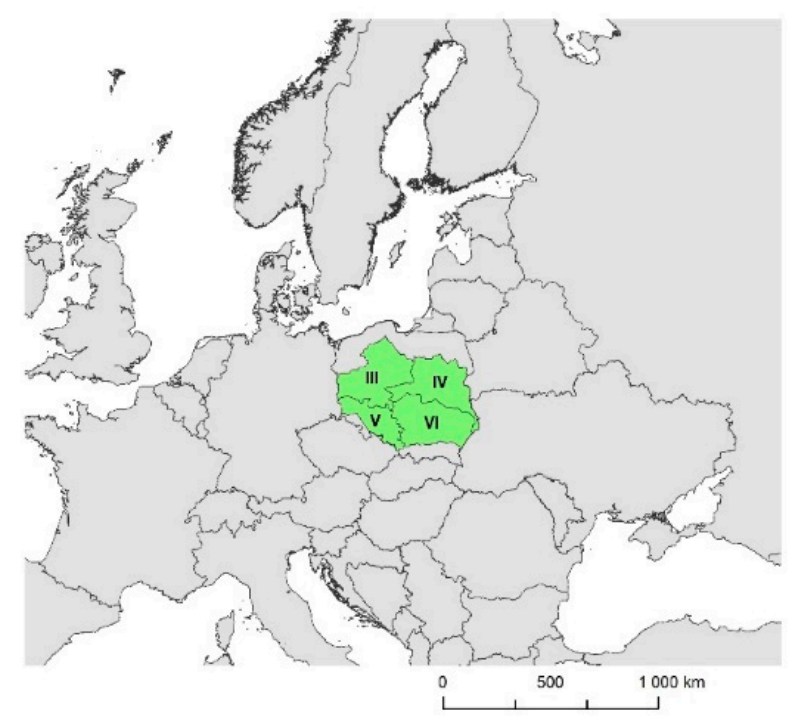

Figure 1. Location of the study area (green) on a map of Europe. 
Table 1. Characteristics of the study area [14].

\begin{tabular}{|c|c|c|c|c|c|c|c|}
\hline $\begin{array}{c}\text { Area } \\
\left(\mathrm{km}^{2}\right)\end{array}$ & $\begin{array}{c}\text { Forest Area } \\
\left(\mathrm{km}^{2}\right)\end{array}$ & $\begin{array}{c}\text { Forest Area } \\
(\%)\end{array}$ & $\begin{array}{c}\text { Average. } \\
\text { Annual } \\
\text { Temperature } \\
\left({ }^{\circ} \mathrm{C}\right)\end{array}$ & $\begin{array}{l}\text { Vegetation } \\
\text { Period } \\
\text { (Days) }\end{array}$ & $\begin{array}{c}\text { Average } \\
\text { Annual } \\
\text { Rainfall } \\
\text { (mm) }\end{array}$ & Dominant Forest Site Types & $\begin{array}{c}\text { Elevation } \\
\text { m.a.s.l }\end{array}$ \\
\hline 220,406 & 59,968 & 27 & 8.0 & $200-220$ & $500-650$ & $\begin{array}{c}\text { FCF- } 43 \% \text { FMCF-21\% DCF-8.4\% FMDF- } 11.9 \% \\
\text { FDF- } 8.9 \% \text { MMCF-6\% MMDF- } \% \text { MDF- } \% \text { AF- } 1 \% \\
\text { AAF- } 1 \%, \text { ASF- } 1 \% *\end{array}$ & $40-718$ \\
\hline
\end{tabular}

* FCF—-fresh coniferous forest; FMCF—-fresh mixed coniferous forest; DCF-dry coniferous forest; FMDF—fresh mixed deciduous forest; FDF—fresh deciduous forest; MMCF—-moist mixed coniferous forest, MMDF-moist mixed deciduous forest, MDF-moist deciduous forest, AF-alluvial forest, AAF—ash-alder forest, ASF-alder (swamp) forest.

It is also considerably uniform in terms of elm resources and the roles and numbers of trees of individual species in the tree stands. This homogeneity is indicated by our analysis [14].

The area of the studied region amounts to $220,406 \mathrm{~km}^{2}$. According to data regarding potential natural vegetation, the share of forests with $U$. glabra in the total forested area in optimum conditions should amount to ca. $0.125 \%$ on average, $U$. laevis-ca. $0.6 \%$ and in the case of $U$. minor $-0.75 \%$, including $0.175 \%$ of forests predominated by the species [ 43 ].

\subsection{Methodology}

The results of the study are largely based on studies and observations conducted at 380 forest stands with elms, with 510 localities of trees of individual species. The results of field studies have been supplemented with data from forest inventories. As a result of our application, we received from the Forest Database an Excel spreadsheet with data on all the forest plots where elms were recorded during the last forest survey (about 35,000 records). These data are also available but in a distributed form in the Forest Data Bank [44].

Both in analyses based on forest inventories and in our field studies a localization of a specific elm species was understood as a forest subdivision within which representatives of the species were found. A forest subdivision is the smallest forest unit with its own description in forest documentation. It is a forest stand with a specific, fairly uniform composition, age, and structure, in respect of which specified silviculture procedures are performed. Acceptance of a subdivision as a locality of elm enabled us to make use of the descriptive data included in forest documentation for its characterization. The subdivision numbers unambiguously define their geographical locations and provide some additional data: subdivision area, forest site type, layer composition, shares, and ages of elms. The subdivision is also often referred to as a 'forest plot' (FP) or a 'forest stand.' The terms will be used in the remaining part of this paper $[13,14]$.

Reduced area (representing an estimation of real area currently covered by elms) was calculated by multiplying the area of the plot with elms by the share of elms in the forest stand (ranked on a scale of 1-10, roughly corresponding to $10-100 \%$ with increasing rank). For example, for a rank of 1 , the plot area was multiplied by 0.1 , for rank 2 , it was multiplied by 0.2 , etc. For the rank "locally" (below $10 \%$ and above $5 \%$ ), the multiplier was 0.075 , while for the rank "individually" (below 5\%), it was 0.025 .

The total number of localities analyzed in this paper is higher than the number of the selected FPs, because elms of different species were treated as separate positions; the same is true for the elms of the same species that formed distinct groups in different structural layers of a given FP $[13,14]$.

During the field survey, we verified the data included in the detailed FP descriptions, available in offices of individual forest districts and in the online Forest Database [44]. We assessed visually the proportion of elm (a percentage proportion of the projected crown area in a given layer). First of all, we identified elm species and determined if they showed DED symptoms. DED occurrence was determined on the basis of its commonly known symptoms $[13,14,45]$.

In the field, sites were classified primarily on the basis of land topography, especially the position of a given locality in relation to topographic features related to watercourses 
and water reservoirs. The adopted classification distinguishes major rivers-with an average flow of over $10 \mathrm{~m}^{3} / \mathrm{s}$, usually with a distinct flood plain and levees and minor rivers-with a flow of below $10 \mathrm{~m}^{3} / \mathrm{s}$, usually with a small flood plain and with no levees. Localities connected with major rivers were additionally subdivided into those situated between the riverbed and levees (i.e., generally between the levees on the both banks of the river), those on levees themselves, and those beyond them.

In order to characterize the localities with elms, use was also made of stand descriptions of individual subdivisions (FPs) and the 'forest site type' (FST) established for them. FST is a basic unit in forest site classification, encompassing all forest areas (FPs) with similar site conditions and production capabilities. FST is determined above all on the basis of an evaluation of the soil conditions (form of humus, soil type, origin of subsoil, mechanical composition of soil, groundwater level).

Tree age was established mostly on the basis of data from the 'stand descriptions' of individual forest plots $[12,13,44]$.

Differences in distributions of the analyzed features were tested using the chi-square test of goodness of fit and independence and the chi-square test with the Yats' correction for continuity. The significance level was set at $\alpha=0.05$.

The frequency distribution of the localities of individual elms within various types of sites was tested in the following variants:

- Distributions of separate data for all site types identified in a given classification.

- Distributions of data from alluvial (AF) site types only (these habitats are particularly related to elms) in the first classification (based on the topography).

- Distributions of summary data from alluvial (AF) and from oak-hornbeam (OHF/fresh deciduous forest and fresh mixed deciduous forest) site types (the oakhornbeam forest potentially has habitats with the largest area in Poland).

- Distributions of summary data from 'moist' and from 'fresh' site types.

- Distributions of data for slope forest (SF) site and for sum data from other site types.

The above-mentioned distributions were tested jointly for all three elms and in pairs between individual species. For the analyses, the application Statistica version 8.0 (StatSoft Polska Inc., Tulsa, OK, USA) was used [46].

\section{Results}

3.1. Results Are Based on Actual Data and Were Prepared on the Basis of the Forest Inventory (without Division into Species)

\subsubsection{Number and Area of Forest Plots with Elms}

According to the most recent survey of forest stands, which is regularly conducted in state-owned forests by the Bureau for Forest Management and Geodesy, in the studied area, elms were found in 34,583 FPs (forest subdivisions). The total area of FPs with elms amounts to $133,630 \mathrm{ha}$. In an overwhelming majority of FPs in which elms are to be found (Table 2), they constitute 5-10\% of the composition-there are 23,412 such subdivisions (FPs). FPs with that percentage of elm have the biggest area, 95,258 ha (Table 2), i.e., they make up about $3 \%$ of all forests, and have the biggest reduced area of the studied tree species. Interestingly, the number of FPs with a share up to $5 \%$ that occupy the second place is much smaller-only 5523 FPs; their area amounts to 21,863 ha. In the studied area, there are only 162 FPs with a $100 \%$ share of elms, and they occupy 378 ha. The total reduced area amounts to 10,708 ha, i.e., about $0.3 \%$ of the total area of the forests in the studied region, 837 ha of which are forest stands predominated by elms (a share of 50-100\%), and 9869 ha are forest stands in which elms are an admixture, of which 7690 ha are forest stands in which they grow locally or individually (a share of less than 10\%) (Table 2). The number of localities of the studied tree species in the region's forest districts oscillates between 5-6 and over 1600, i.e., it varies a lot. The presented data indicate that the studied species occupies just a fraction of one percent of the forest area of the region covered by the study. 
Table 2. Number and area of forest plots with elms in the study zone, with a subdivision into classes of their share in the forest stand.

\begin{tabular}{cccc}
\hline Share of Elms in Forest Stands & No & Area (ha) & Reduced Area (ha) \\
\hline$<5 \%$ & 5523 & 21,863 & 546 \\
$5-10 \%$ & 23,412 & 95,258 & 7144 \\
$10 \%$ & 3552 & 10,830 & 1083 \\
$20 \%$ & 1092 & 3198 & 639 \\
$30 \%$ & 389 & 957 & 287 \\
$40 \%$ & 174 & 425 & 170 \\
$50 \%$ & 102 & 200 & 100 \\
$60 \%$ & 70 & 229 & 137 \\
$70 \%$ & 53 & 126 & 88 \\
$80 \%$ & 40 & 135 & 108 \\
$90 \%$ & 14 & 27 & 24 \\
$100 \%$ & 162 & 378 & 378 \\
\hline
\end{tabular}

Reduced area representing an estimation of real area currently covered by elm trees.

\subsubsection{Age Distribution}

In the general age distribution of elms in the studied region (Figure 2), similarly to the average age distribution of all forest trees in Poland [47], the most numerous are elms aged 40-60 years. What differs from the latter distribution is a bigger percentage of elms of up to 20 years of age. Elms of that age predominate in forest stands in which they are the dominating species (Figure 3). The age distributions of all elms and forests in Poland presented in Figure 2A did not differ statistically (chi-square $=4.73, p=0.58$ ). On the other hand, significant difference (chi-square $=308.46, p=0.001$ ) occurs between the age distribution of forests and the distribution of the average age of elms at localities where the elm has a dominant position (Figure 2B).

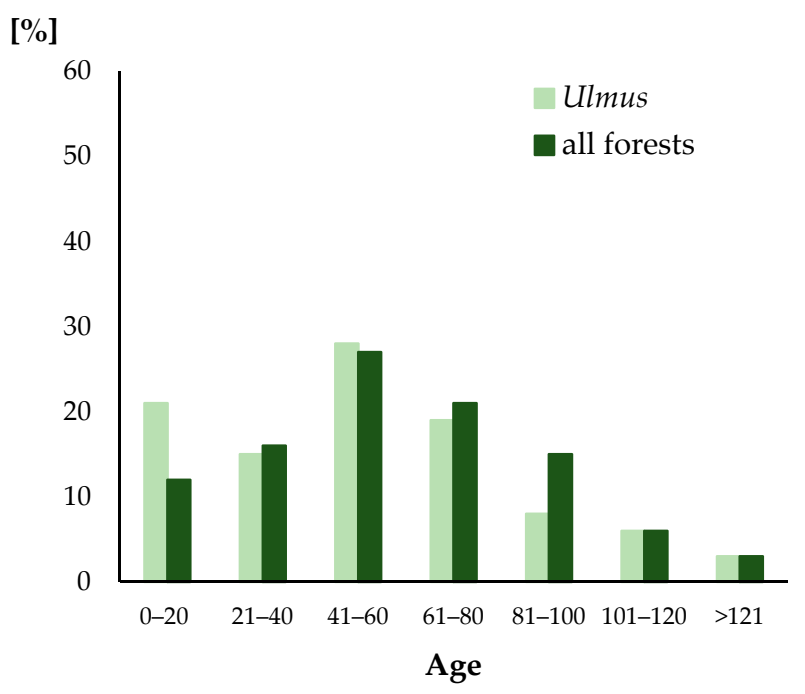

(A)

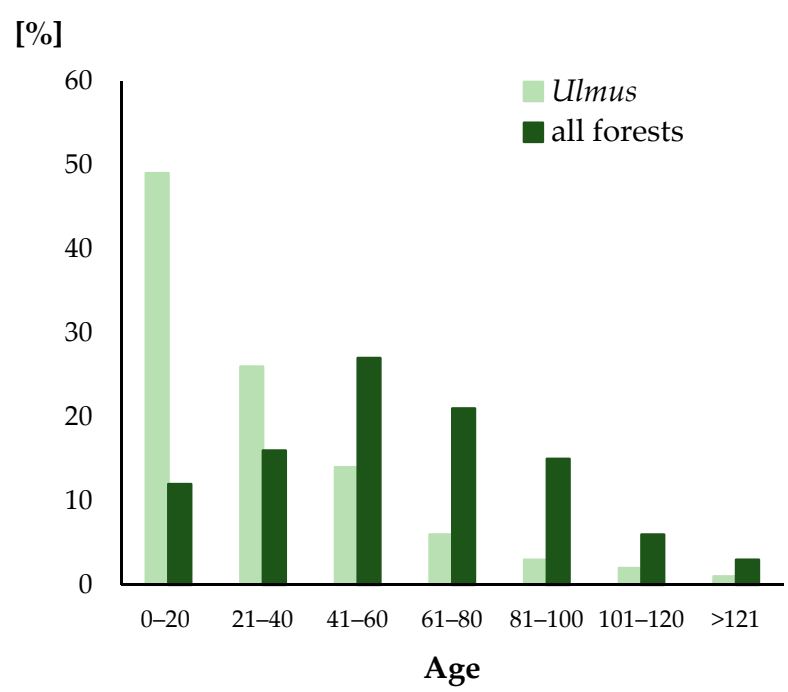

(B)

Figure 2. The age distributions of all elms (A) and elms in stands where they have a dominant position (B) compared with all forests in Poland. 


\subsubsection{Site Preferences}

As regards forest site types, the biggest number of localities are fresh deciduous forest sites, followed by fresh mixed deciduous forests, moist deciduous forests, alluvial forests, and fresh mixed coniferous forests (Table 3).

The distribution of the resources does not correspond to site preferences. The first characteristic is largely affected by the area occupied by a specific site type. The other (preference) is better reflected by the number of localities per area unit of a specific site type (Figures 3 and 4). In this case, the first place is occupied by alluvial forests, with nearly 20 localities per $1 \mathrm{~km}^{2}$ of the site, and the second place by moist deciduous forests with ca. 8.5 localities, i.e., a site that, according to phytosociologists, in $50 \%$ of cases occupies potentially alluvial (riparian) sites. Next comes ash alder, with over six localities. In the case of fresh deciduous forests, the appropriate value amounts to 2.6, for typical alder forests-2.0, for moist mixed deciduous forests-1.4, for fresh mixed deciduous forests-ca. 1.0 , and for fresh coniferous forests, the last on the list, just 0.03 . The presented data indicate that in the studied area, the genus elm may occur in a broad spectrum of forest site types, but it clearly favors fertile and moist sites, particularly riparian ones.

Distributions of number of forest plots with elms and total wooded area in Poland in forest sites of various types (Table 3 ) differ significantly (chi-square $=786.69, p=0.00$ ).

Table 3. Percentage distributions of the number of forest plots with elms (No. Ulmus) and total wooded area in Poland in forest sites of various types (FST). c.f.-coniferous forest, d.f.- deciduous forest.

\begin{tabular}{ccc}
\hline FST & No. Ulmus & Wooded Area \\
\hline ash-alder forest & 5.2 & 0.8 \\
alder forest & 3.0 & 1.5 \\
alluvial forest & 12.4 & 0.6 \\
moist d.f. & 18.0 & 2.0 \\
moist mixed d.f. & 7.4 & 4.9 \\
moist mixed c.f. & 1.1 & 6.3 \\
fresh d.f. & 27.5 & 10.1 \\
fresh mixed d.f. & 18.4 & 18.1 \\
fresh mixed c.f. & 5.8 & 28.3 \\
fresh c.f. & 1.1 & 27.5 \\
\hline Chi test & & \\
chi-square & & 786.69 \\
degrees of freedom & & 9 \\
$p$-value & & 0.000 \\
Yats' chi-square & & 775.3 \\
Yats' $p$-value & & 0.000 \\
\hline
\end{tabular}




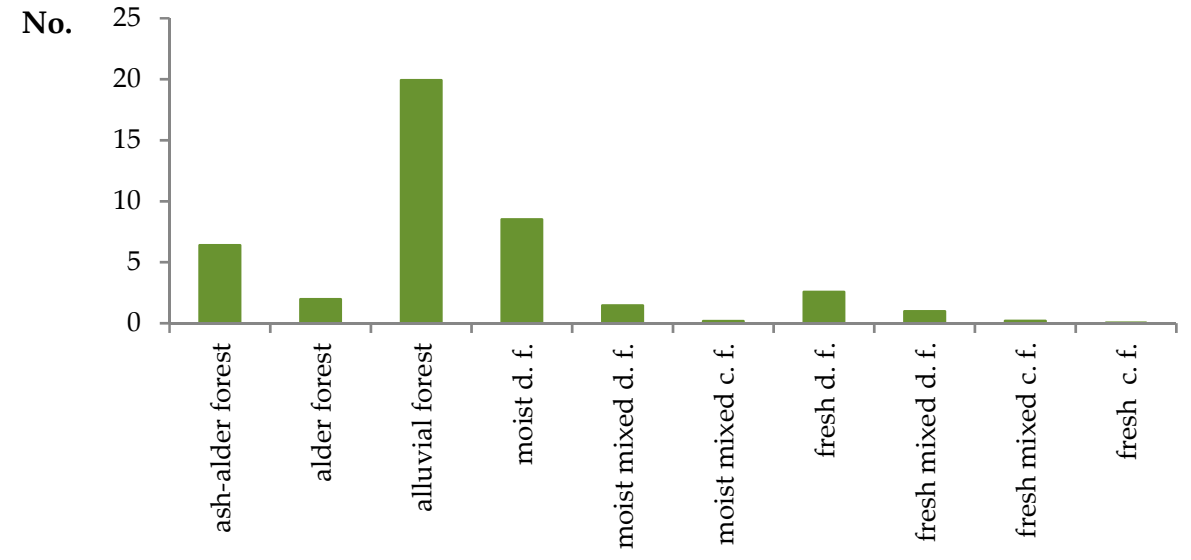

FST

Figure 3. Number of forest plots with elms per $1 \mathrm{~km}^{2}$ of total wooded area in forest sites of various types (FST). c.f.-coniferous forest, d.f.-deciduous forest.

3.2. Results Based on Field Research on (Randomly) Selected Elm Localities (with Division into Species)

3.2.1. Site Preferences of Individual Elm Species

During the field studies, all of the elm species were recorded in all parts of the region covered by the study. Tables $4-7$ and Figures 4 and 5 show the distribution of the localities of individual elm species studied in the field within different types of habitat. Tables 4 and 5 and Figure 4 present data according to a classification of sites based mainly on land topography that was done directly in the field. Tables 6 and 7 and Figure 5 present data according to the so-called 'Forest site type' (FST) classification. FST-related data are entered in forest inventories, in descriptions of FPs (subdivision) in which individual localities are found. The classification is based primarily on soil criteria.

Table 4. Number of individual elm localities within the specific site types distinguished in the field (topographic classification) and chi-square test.

\begin{tabular}{cccc}
\hline Site Type & U. laevis & U. minor & U. glabra \\
\hline ASF & 9 & 0 & 0 \\
AF, L. river, between embank. & 58 & 8 & 1 \\
AF, L. river, embank. & 5 & 3 & 0 \\
AF, L. river, behind embank. & 40 & 11 & 2 \\
AF, S. river & 73 & 7 & 5 \\
O-HF & 191 & 46 & 24 \\
SF & 11 & 3 & 9 \\
FMCF & 3 & 1 & 0 \\
Chi test & & & 49.99 \\
Chi-square & & & $\mathbf{0 . 0 0}$ \\
Degrees offreedom & & & $\mathbf{3 8 . 7 2}$ \\
-value & & & $\mathbf{0 . 0 0}$ \\
Yets' chi-square & & & \\
Yets' $p$-value & & & \\
\hline
\end{tabular}

Bold values indicate statistically significant differences $(p<0.05)$. AF-alluvial forest, ASF-alder swamp forest, FMCF-fresh mixed coniferous forest, $\mathrm{OH}-\mathrm{F}$ - oak-hornbeam or similar forest, SF-slope forest, L. river-at a large river, S. river-near a small watercourse, between embank.-between flood embankments, embank.—area of flood embankments, behind embank.--behind embankments. 


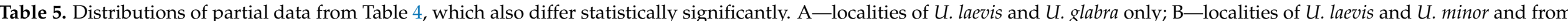

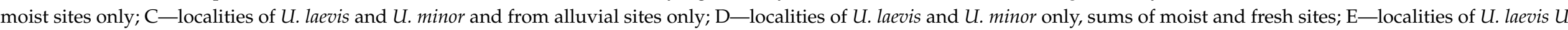

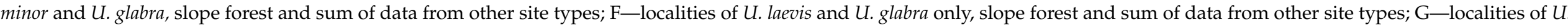
minor and $U$. glabra only, slope forest and sum of data from other site types.

\begin{tabular}{|c|c|c|c|c|c|c|c|c|c|c|c|c|c|c|c|c|c|c|c|c|c|}
\hline \multicolumn{3}{|c|}{ A } & \multicolumn{3}{|c|}{ B } & \multicolumn{3}{|c|}{$\mathrm{C}$} & \multicolumn{3}{|c|}{ D } & \multicolumn{4}{|c|}{ E } & \multicolumn{3}{|c|}{$\mathbf{F}$} & \multicolumn{3}{|c|}{ G } \\
\hline Site Type & $\begin{array}{c}\text { U. } \\
\text { laevis }\end{array}$ & $\begin{array}{c}\text { U. } \\
\text { glabra }\end{array}$ & Site Type & $\begin{array}{c}\text { U. } \\
\text { laevis }\end{array}$ & $\begin{array}{c}U . \\
\text { minor }\end{array}$ & Site Type & $\begin{array}{c}U . \\
\text { laevis }\end{array}$ & $\begin{array}{c}U . \\
\text { minor }\end{array}$ & $\begin{array}{c}\text { Habitat } \\
\text { Type }\end{array}$ & $\begin{array}{c}U . \\
\text { laevis }\end{array}$ & $\begin{array}{c}U \text {. } \\
\text { minor }\end{array}$ & TSL & $\begin{array}{c}\text { U. } \\
\text { laevis }\end{array}$ & U.minor & $\begin{array}{c}\text { U. } \\
\text { glabra }\end{array}$ & TSL & $\begin{array}{c}U . \\
\text { laevis }\end{array}$ & $\begin{array}{c}\text { U. } \\
\text { glabra }\end{array}$ & TSL & U.minor & $\begin{array}{c}\text { U. } \\
\text { glabra }\end{array}$ \\
\hline ASF & 9 & 0 & ASF & 9 & 0 & $\begin{array}{l}\text { AF, L. } \\
\text { river, } \\
\text { between }\end{array}$ & 58 & 8 & $\begin{array}{l}\text { Moist } \\
\text { sites }\end{array}$ & 180 & 26 & $\begin{array}{l}\text { slope } \\
\text { forest }\end{array}$ & 9 & 3 & 11 & $\begin{array}{l}\text { slope } \\
\text { forest }\end{array}$ & 9 & 11 & $\begin{array}{l}\text { slope } \\
\text { forest }\end{array}$ & 3 & 11 \\
\hline $\begin{array}{l}\text { AF, L. } \\
\text { river, } \\
\text { between } \\
\text { embank. }\end{array}$ & 58 & 1 & $\begin{array}{l}\text { AF, L. } \\
\text { river, } \\
\text { between } \\
\text { embank. }\end{array}$ & 58 & 8 & embank. & & & $\begin{array}{l}\text { Fresh } \\
\text { sites }\end{array}$ & 210 & 53 & $\begin{array}{l}\text { other site } \\
\text { types }\end{array}$ & 379 & 76 & 32 & $\begin{array}{l}\text { other site } \\
\text { types }\end{array}$ & 379 & 32 & $\begin{array}{l}\text { other site } \\
\text { types }\end{array}$ & 76 & 32 \\
\hline $\begin{array}{l}\text { AF, L. } \\
\text { river, } \\
\text { embank. } \\
\text { AF, L. }\end{array}$ & 5 & 0 & $\begin{array}{l}\text { AF, L. } \\
\text { river, } \\
\text { embank. } \\
\mathrm{AF}, \mathrm{L} \text {. }\end{array}$ & 5 & 3 & $\begin{array}{l}\mathrm{AF}, \mathrm{L} . \\
\text { river, } \\
\text { embank. } \\
\mathrm{AF}, \mathrm{L} \text {. }\end{array}$ & 5 & 3 & & & & & & & & & & & & & \\
\hline $\begin{array}{l}\text { river, } \\
\text { behind } \\
\text { embank. }\end{array}$ & 40 & 2 & $\begin{array}{l}\text { river, } \\
\text { behind } \\
\text { embank. }\end{array}$ & 40 & 11 & $\begin{array}{l}\text { river, } \\
\text { behind } \\
\text { embank. }\end{array}$ & 40 & 11 & & & & & & & & & & & & & \\
\hline $\begin{array}{l}\text { AF, S. } \\
\text { river }\end{array}$ & 73 & 5 & $\begin{array}{l}\mathrm{AF}, \mathrm{S} . \\
\text { river }\end{array}$ & 73 & 7 & $\begin{array}{l}\mathrm{AF}, \mathrm{S} . \\
\text { river }\end{array}$ & 73 & 7 & & & & & & & & & & & & & \\
\hline $\mathrm{O}-\mathrm{HF}$ & 191 & 24 & & & & & & & & & & & & & & & & & & & \\
\hline $\begin{array}{l}\text { SF } \\
\text { FMCF }\end{array}$ & $\begin{array}{c}11 \\
3\end{array}$ & $\begin{array}{l}9 \\
0\end{array}$ & & & & & & & & & & & & & & & & & & & \\
\hline Chi Test & & & Chi Test & & & Chi Test & & & Chi Test & & & Chi Test & & & & Chi Test & & & Chi Test & & \\
\hline $\begin{array}{l}\text { Chi- } \\
\text { square }\end{array}$ & & 37.89 & $\begin{array}{l}\text { Chi- } \\
\text { square }\end{array}$ & & 9.82 & $\begin{array}{l}\text { Chi- } \\
\text { square }\end{array}$ & & 8,05 & $\begin{array}{c}\text { Chi- } \\
\text { square }\end{array}$ & & 4.67 & $\begin{array}{l}\text { chi- } \\
\text { square }\end{array}$ & & & 48.75 & $\begin{array}{c}\text { chi- } \\
\text { square }\end{array}$ & & 47.34 & $\begin{array}{l}\text { chi- } \\
\text { square }\end{array}$ & & 13.01 \\
\hline$p$-value & & 0 & $p$-value & & 0.04 & $p$-value & & 0.04 & $p$-value & & 0.03 & $p$-value & & & 0 & $p$-value & & 0 & $p$-value & & 0 \\
\hline $\begin{array}{l}\text { Yats' chi- } \\
\text { square }\end{array}$ & & 30.62 & $\begin{array}{l}\text { Yats' chi- } \\
\text { square }\end{array}$ & & 6 & $\begin{array}{l}\text { Yats' chi- } \\
\text { square }\end{array}$ & & 5.25 & $\begin{array}{l}\text { Yats' chi- } \\
\text { square }\end{array}$ & & 4.155 & $\begin{array}{l}\text { Yats' chi- } \\
\text { square }\end{array}$ & & & 43.41 & $\begin{array}{l}\text { Yats' chi- } \\
\text { square }\end{array}$ & & 42.23 & $\begin{array}{l}\text { Yats' chi- } \\
\text { square }\end{array}$ & & 10.95 \\
\hline $\begin{array}{l}\text { Yats' } \\
p \text {-value }\end{array}$ & & 0 & $\begin{array}{l}\text { Yats' } \\
p \text {-value }\end{array}$ & & 0.2 & $\begin{array}{l}\text { Yats' } \\
p \text {-value }\end{array}$ & & 0.15 & $\begin{array}{c}\text { Yats' } \\
p \text {-value }\end{array}$ & & 0.04 & $\begin{array}{l}\text { Yats' } \\
p \text {-value }\end{array}$ & & & 0 & $\begin{array}{c}\text { Yats' } \\
p \text {-value }\end{array}$ & & 0 & $\begin{array}{l}\text { Yats' } \\
p \text {-value }\end{array}$ & 3 & 0.001 \\
\hline
\end{tabular}

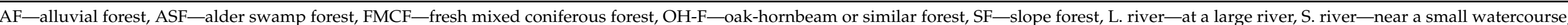
between embank._-between flood embankments, embank._area of flood embankments, behind embank._behind embankments. 


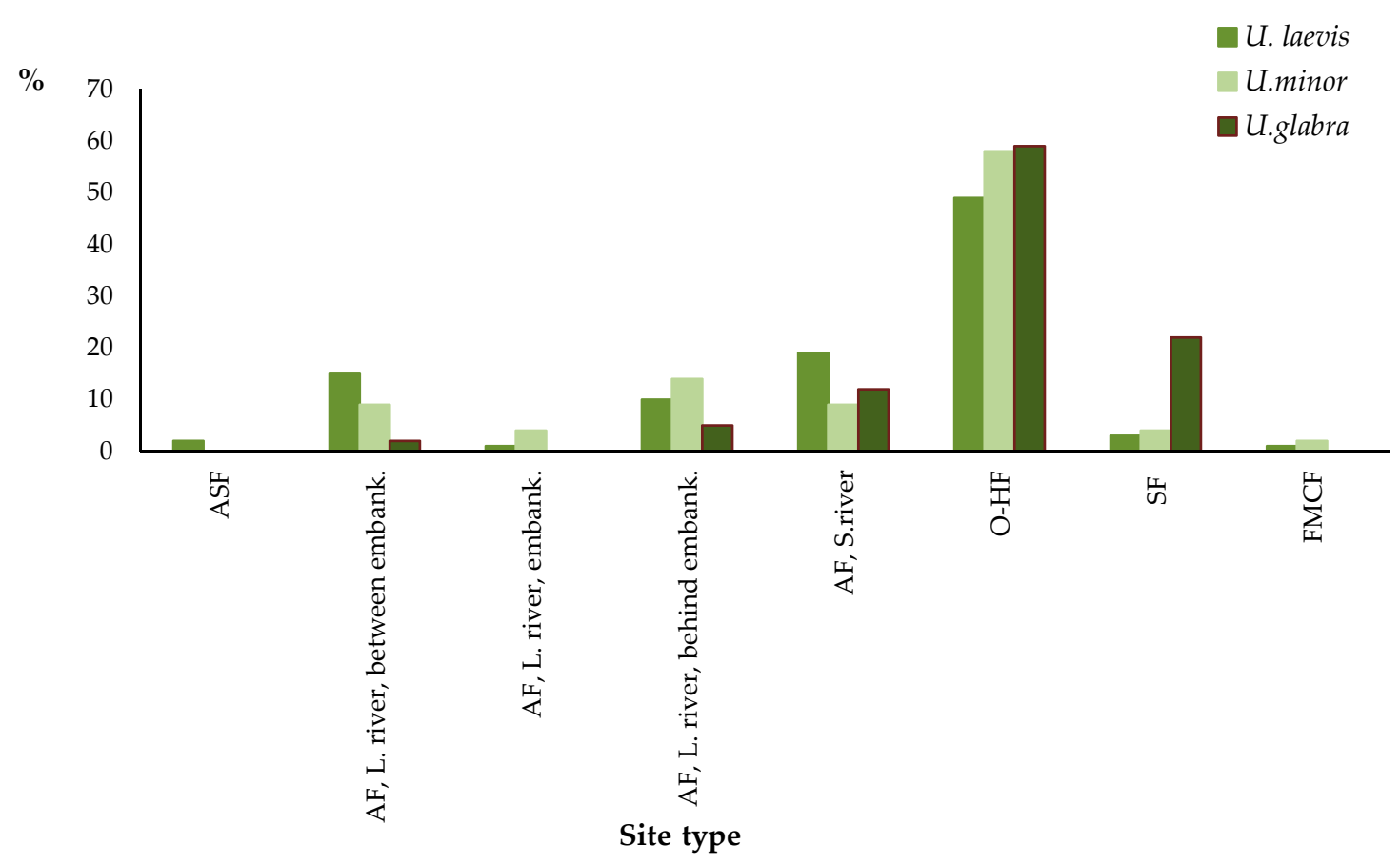

Figure 4. Percentage of individual elm localities within the specific site types distinguished in the field (topographic classification). AF-alluvial forest, ASF-alder swamp forest, FMCF-fresh mixed coniferous forest, OH-F-oak-hornbeam or similar forest, SF-slope forest, L. river-at a large river, S. river-near a small watercourse, between embank.-between flood embankments, embank.—area of flood embankments, behind embank.-behind embankments.

Table 6. Number of individual elm localities in 'forest site types' (FST) according to forest documentation (distinguished by soil classification) and chi-square test.

\begin{tabular}{cccc}
\hline TSL & U. laevis & U.minor & U. glabra \\
\hline ash-alder forest & 5 & 1 & 0 \\
alder forest & 4 & 0 & 0 \\
alluvial forest & 59 & 7 & 1 \\
moist d.f. & 74 & 12 & 4 \\
moist mixed d.f. & 35 & 7 & 2 \\
moist mixed c.f. & 8 & 0 & 1 \\
fresh mixed d.f. & 82 & 23 & 16 \\
fresh d.f. & 120 & 27 & 17 \\
fresh mixed c.f. & 3 & 2 & 0 \\
\hline Chi test & & & \\
\hline chi-square & & & 16 \\
degrees offreedom & & & 0.1342 \\
$p$-value & & & 14.628 \\
Yats' chi-square & & \\
Yats' $p$-value & &
\end{tabular}




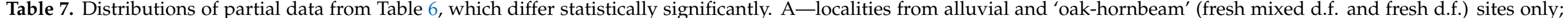

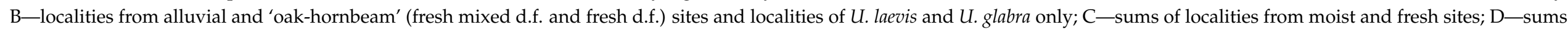
of localities from moist and fresh sites, localities of $U$. laevis and $U$. minor only; E-sums of localities from moist and fresh sites, localities of $U$. laevis and $U$. glabra only.

\begin{tabular}{|c|c|c|c|c|c|c|c|c|c|c|c|c|c|c|c|c|}
\hline \multicolumn{4}{|c|}{ A } & \multicolumn{3}{|c|}{ B } & \multicolumn{4}{|c|}{ C } & \multicolumn{3}{|c|}{ D } & \multicolumn{3}{|c|}{ E } \\
\hline TSL & $\begin{array}{c}\text { U. } \\
\text { laevis }\end{array}$ & U.minor & $\begin{array}{c}\text { U. } \\
\text { glabra }\end{array}$ & TSL & $\begin{array}{c}\text { U. } \\
\text { laevis }\end{array}$ & $\begin{array}{c}\text { U. } \\
\text { glabra }\end{array}$ & TSL & $\begin{array}{c}\text { U. } \\
\text { laevis }\end{array}$ & U.minor & $\begin{array}{c}\text { U. } \\
\text { glabra }\end{array}$ & TSL & $\begin{array}{c}\text { U. } \\
\text { laevis }\end{array}$ & $\begin{array}{c}U . \\
\text { minor }\end{array}$ & TSL & $\underset{\text { laevis }}{U .}$ & $\begin{array}{c}\text { U. } \\
\text { glabra }\end{array}$ \\
\hline alluvial forest & 59 & 7 & 1 & alluvial forest & 59 & 1 & moist sites & 185 & 27 & 8 & moist sites & 185 & 27 & moist sites & 185 & 8 \\
\hline $\begin{array}{l}\text { fresh mixed d.f. and } \\
\text { fresh d.f. }\end{array}$ & 202 & 50 & 33 & $\begin{array}{l}\text { fresh mixed d.f. } \\
\text { and fresh d.f. }\end{array}$ & 202 & 33 & fresh sites & 205 & 52 & 33 & fresh sites & 205 & 52 & fresh sites & 205 & 33 \\
\hline Chi test & & & & Chi test & & & Chi test & & & & Chi test & & & Chi test & & \\
\hline chi-square & & & 9.651 & chi-square & & 7.179 & chi-square & & & 14.853 & chi-square & & 4.662 & chi-square & & 11.699 \\
\hline degrees of freedom & & & 2 & $\begin{array}{l}\text { degrees of } \\
\text { freedom }\end{array}$ & & 1 & $\begin{array}{l}\text { degrees of } \\
\text { freedom }\end{array}$ & & & 2 & $\begin{array}{l}\text { degrees of } \\
\text { freedom }\end{array}$ & & 1 & $\begin{array}{l}\text { degrees of } \\
\text { freedom }\end{array}$ & & 1 \\
\hline$p$-value & & & 0.0084 & $p$-value & & 0.007 & $p$-value & & & 0.0006 & $p$-value & & 0.0308 & $p$-value & & 0.00063 \\
\hline Yats' chi-square & & & 7.929 & $\begin{array}{l}\text { Yats' } \\
\text { chi-square }\end{array}$ & & 6.017 & Yats' chi-square & & & 13.39 & $\begin{array}{l}\text { Yats' } \\
\text { chi-square }\end{array}$ & & 4.142 & $\begin{array}{l}\text { Yats' } \\
\text { chi-square }\end{array}$ & & 10.597 \\
\hline Yats' $p$-value & & & 0.0189 & Yats' $p$-value & & 0.014 & Yats' $p$-value & & & 0.0124 & Yats' $p$-value & & 0.0418 & Yats' $p$-value & & 0.00113 \\
\hline
\end{tabular}




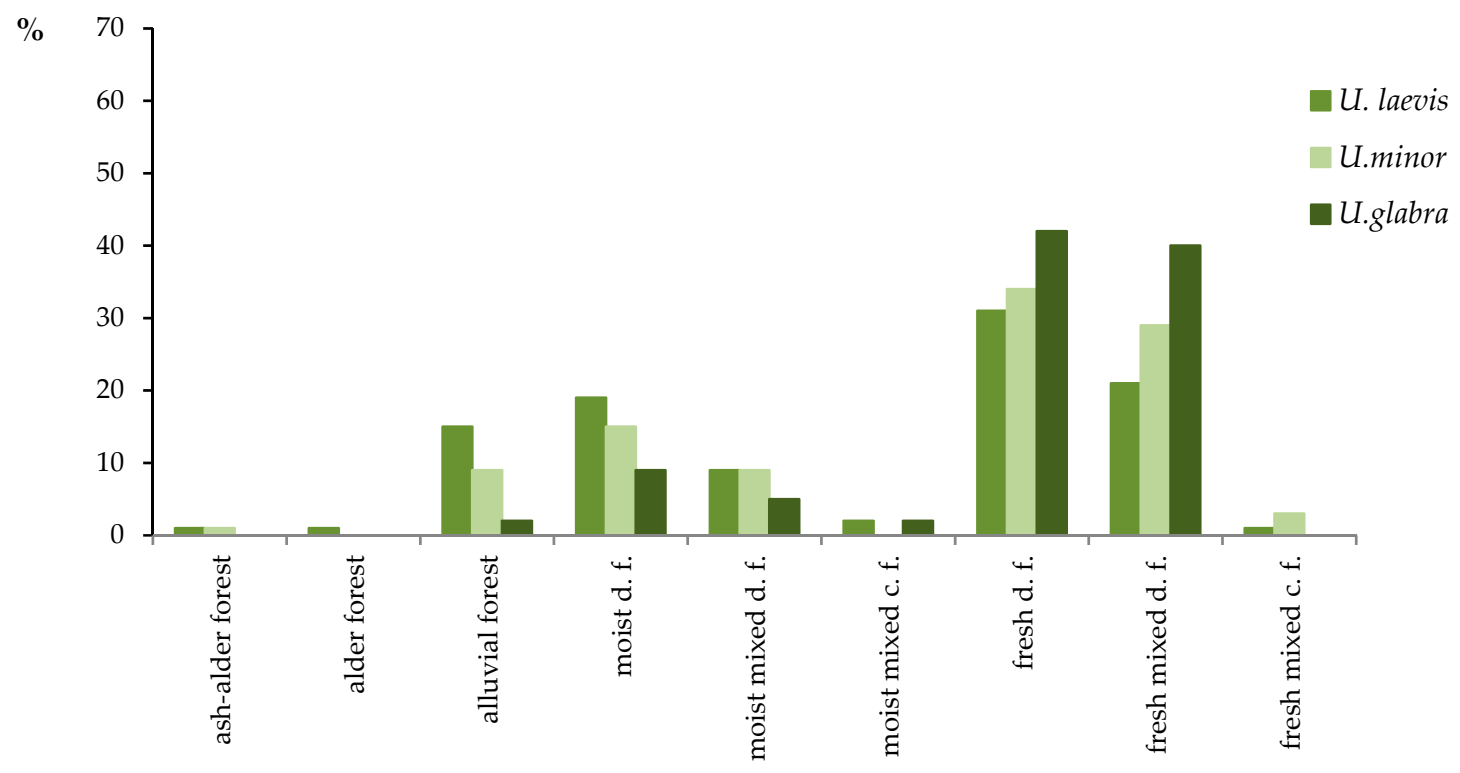

Site type

Figure 5. Percentage of individual elm localities in 'forest site types' (FST) according to forest documentation (distinguished by soil classification). c.f.-coniferous forest, d.f.-deciduous forest.

Figures 4 and 5 show the data as percentages of the total number of the examined localities of a given species (accepted as 100\%).

The first thing to notice in Illustrations $9 \mathrm{a}$ and $10 \mathrm{a}$ is a noticeable quantitative superiority of $U$. laevis in all of the identified types. The species grows at 390 out of 510 identified localities. Its domination is even more conspicuous if we consider localities at which elm predominates over other species or localities with elms older than 50 years. In the first case, out of 147 localities, 137 include $U$. laevis; in the second case, out of the total 242 examined localities, 232 have this elm.

An analysis of the percentage data indicates different preferences of individual elm species as to site type. As regards all species, the biggest percentage of sites are so-called 'fresh' sites, i.e., ones that are almost always beyond reach of flood waters-in the case in question they are mainly fertile forest site types ("fresh deciduous forest,' 'fresh mixed deciduous forest'), where oak-hornbeam forest communities develop in natural conditions. In the case of $U$. laevis, it is $52 \%$ of localities, according to a site classification done on the ground (topographic classification), and 53\% of localities according to a classification based on soil examinations (classification of FST). As regards $U$. minor, the respective figures are $57 \%$ and $61 \%$, and as regards $U$. glabra $-81 \%$ and $82 \%$. As mentioned before, the predominant number of localities in fresh sites (soils) does not result from the fact that elms favor such soils, but rather from the large area of such sites.

As might be expected, the biggest share of localities developing at moist sites has been recorded in the case of $U$. laevis, which-in comparison with the field elm, which also prefers such conditions-occurs more frequently at locations in active flooding zones in between levees of major rivers or in immediate proximity of the bed of minor rivers with no levees. $U$. minor has relatively (in terms of percentage) more localities on levees and in former riparian areas of major rivers situated beyond levees. This elm also has a bigger share at oak-hornbeam forest sites. Relatively weakest preferences for moist sites in the studied region are noticeable in the case of $U$. glabra. However, if we consider that the area of fresh sites is over five times bigger than that of the moist sites, it means that this species also favors sites with a moist subsoil. If the areas of the sites developing on 
moist and fresh soils were equal, the localities of $U$. glabra on moist-soil sites would amount to $55 \%$ according to the classification based on land topography (done on the ground) or $53 \%$ according to the forest site type classification. In the case of $U$. laevis and $U$. minor, this would amount to $83 \% / 82 \%$ and $80 \% / 77 \%$, respectively. The actual share of moist sites increases if we only consider FPs where the elm predominates (share $>50 \%$ ). In that case, the share of $U$. laevis amounts to $53 \%$ according classification done on the ground. The theoretical share (with the areas of the fresh and moist sites being equal) would then amount to $86 \%$. The corresponding values for $U$. minor are $50 \%$ and $84 \%$, but because of the small amount of data for this species (nine localities), the result should be regarded as not very accurate. Where the number of distinguished units is small, addition to or removal from the list of even one area may considerably affect the final result.

Tables 4, 5 and 7 present the statistically different distributions of individual elm localities within the site types.

A distinguishing element in the case of the wych elm is an exceptionally big share of its localities on slopes (the 'topographic' classification), which amounts to $22 \%$, while for $U$. laevis it is $3 \%$, and $U$. minor- $4 \%$. According to the TSL classification, all of the distinguished localities on slopes are regarded as 'fresh' sites.

\subsubsection{The Occurrence of DED Depends on the Species of Elm and the Habitat}

Figure 6 shows the number of localities at which DED signs have been observed in relation to the total numbers of localities of individual species. Some significant differences between individual species can be seen, while the differences between the sites do not seem material. The distributions of all localities and localities with DED signs at moist and dry sites for all species (Figure 7) do not differ statistically (chi-square $=1.75, p=0.42$ ). Despite the scattering and the small number of $U$. minor localities, as many as 34 out of $79(43 \%)$ localities of the tree showed clear DED signs (Figure 7).

No.

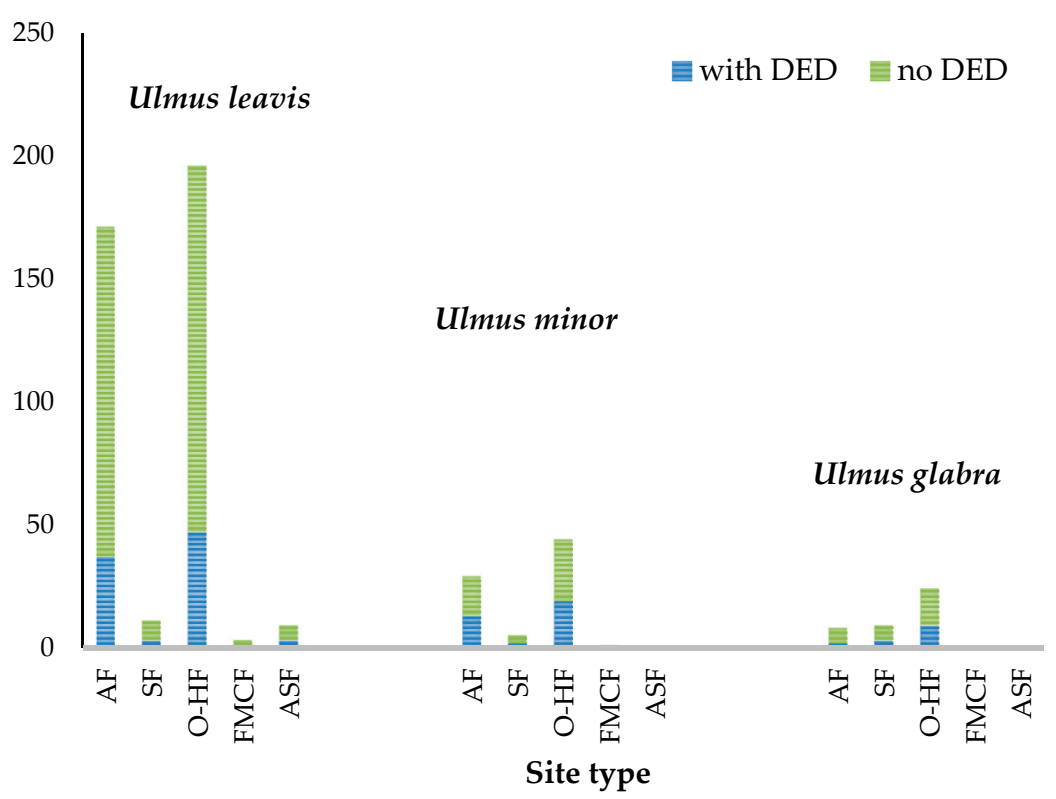

Figure 6. Occurrence of Dutch Elm Disease (DED) symptoms in the study area. AF-alluvial forest, $\mathrm{SF}$-slope forest, $\mathrm{O}-\mathrm{HF}$ - oak-hornbeam or similar forest, FMCF-fresh mixed coniferous forest, ASF-alder swamp forest. 


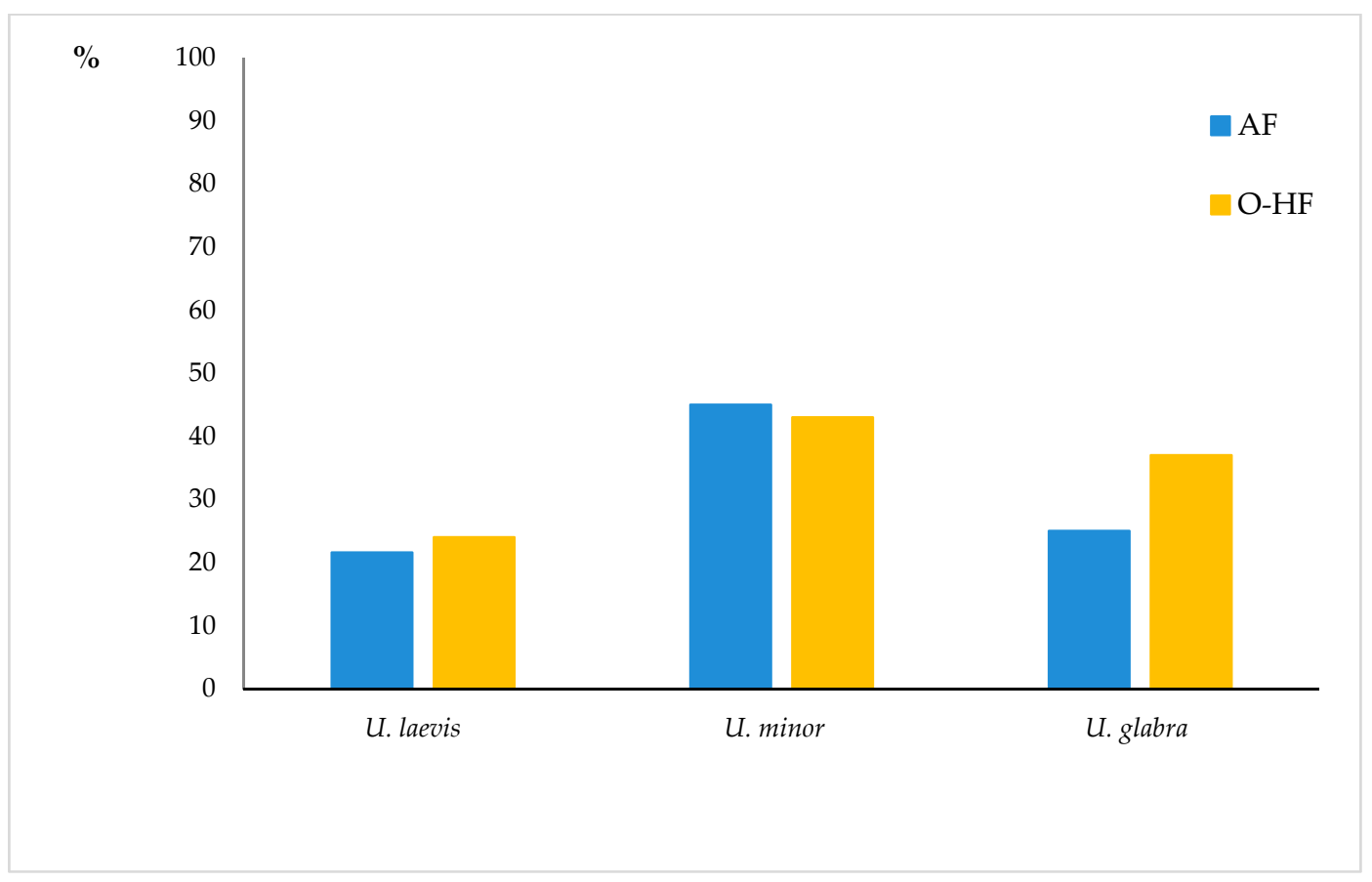

Figure 7. The percentage of the U. laevis, U. minor, and U. glabra localities with DED symptoms on plains of Poland. AF-alluvial forest; O-HF-oak-hornbeam forest.

Trees with symptoms of the disease have been found throughout the studied region. Nowadays, $U$. minor principally occurs in the form of young specimens, often of the sucker origin, growing along forest rims, lynchets, forest roads, and within small, multi-species loose clumps with bushes and short trees. Quite often, field elms also grow under a canopy of older trees, including older European white elms. U. laevis displays the lowest percentage of localities with DED symptoms-23\%, which seems to confirm a suggestion that elm bark beetles, which spread DED, less willingly inhabit this elm species [48]. However, the rather significant percentage of localities with typical DED signs and a confirmation of its presence in phytopathologic examinations indicate that the species cannot be claimed to be resistant to the pathogen. Infection symptoms in this elm are most frequently noticed in older trees, but specimens of $U$. laevis with visible signs of feeding by large elm bark beetles are also observed in trees that are about 10 years old. The percentage of the wych elm with the disease symptoms was higher, at $34 \%$.

\section{Discussion}

\subsection{Age Distribution}

The bigger number of younger forest stands in the elm age distributions (Figure 2) is partly connected to a mass dying of ashes. This has encouraged some foresters to partly replace the species with elms. Both species are recommended for cultivation on riparian sites and in moist forests, but in recent years, it has been ash that was pushing out elm from cultivation [49]. The bigger share of localities with younger elms in all number of elms localities may also be attributable to the fact presented by Colinn et al. [4] that the beetles that spread DED do not feed in crowns of elms shorter than $3 \mathrm{~m}$, which limits the occurrence of the pathogen in the youngest age classes.

Data from stands, in which the elm dominate (Figure 2B), suggests that DED pressure is particularly strong here.

\subsection{Number and Area of Forest Plots with Elms}

The presented data indicate that the studied species occupies just a fraction of one percent of the forest area of the region covered by the study (only about $0.3 \%$ of the forested area). The result seems more favorable if it is referred to data based on potential 
natural vegetation. In the light of the study by Matuszkiewicz [43], based on the analysis of potential communities, in optimum conditions, the field elm should be the predominant elm species in the studied region. According to the data presented in the source, in optimum conditions, in the studied region, the total area of forest stands which should include elms should not exceed $1.47 \%$ of the actual total forested area, which is a surprisingly small figure. The forest inventory documentation (which contains relatively accurate data) indicates that the subdivisions (FPs) with elms currently account for over $3 \%$ of the forested area, i.e., about twice as much. However, in this case about $53 \%$ of the FPs with elms are located in 'fresh' habitats, especially fresh deciduous forests and fresh mixed deciduous forests, which —as suggested by tabular listings—were not included by Matuszkiewicz [43], probably because an overwhelming majority of the forest stands at those sites do not comprise elms. If only moist sites are considered, the actual area of the FPs with elm falls to ca. $1.35 \%$. Consequently, in comparison with the optimum conditions, a slight deficit is noticeable. An issue might be the small mean actual share of elms in forest stands. On average, the real area occupied by elms amounts to less than $7 \%$ of the area of the FPs in which elms are to be found. The potential share is likely to be higher. According to Matuszkiewicz's estimated data [43], in the studied region, forest stands with the dominating elm should occupy about $0.75-0.8 \%$ of the forested area, while the actual share of such stands amounts to less than $0.36 \%$, i.e., over one half less. Data regarding the actual area of forest stands with the dominating elm compared with the corresponding data from 1978 [50] indicate a rise in the area of such FPs by ca. 20\% [12]. This may suggest that the reduction in the primary area occupied by elm 40 years ago was bigger than today. It should be remembered that under pressure from $D E D$, forest stands with a large share of elm disappear first.

In the potential conditions [43], all forest stands with the dominating elm were allocated to the species $U$. minor. As regards the other two species, no such natural form was provided for. During the field work, it was recorded that out of 147 examined forest stands with the dominating elm, only 1 was created by $U$. glabra, 9 by $U$. minor, and as many as 137 by $U$. laevis. These facts suggests that at many localities, the European white elm has replaced the field elm. Thanks to this, during the last few decades the resources of elm in Poland have not decreased.

\subsection{The Elms Habitat Preferences}

This issue has already been dealt with in some of the earlier studies $[13,49]$. The results obtained in Wielkopolska [13], and in particular those obtained in Pomerania [49], indicate that $U$. minor prefers slightly drier habitats than $U$. laevis. U. glabra was found to be more frequent on the slopes than other elm species. However, the small amount of data gathered does not allow for definitive conclusions to be drawn. In Greater Poland, U. laevis, U. minor, and $U$. glabra were represented by 147,34 , and 15 localities, respectively [13]. In the case of Pomerania, it was 54, 13, and 24 localities, respectively [49]. Overall, the low number of $U$. minor and $U$. glabra localities indicates the need to have a relatively large amount of data from an area with, if possible, a homogeneous climate and surface features. Changes in these factors may significantly affect habitat preferences and the role of individual species in creating potential natural vegetation [e.g., 1, 2, 4, 8]. For example, U. glabra in northern Europe is often found in the lowlands, while in the south of the continent it clearly prefers mountains $[2,4,8,21]$. The data published earlier [14] indicated that a suitable area, at least as regards the shares of individual species in the total elm resources, is located in the center of Poland (Figure 1). This area is characterized by a similar share of certain habitat types, including riparian forests associated with the large river valleys, and a similar share of individual elm species in the total population of this genus trees. A more diversified area means more variants of elm occurrence and fewer localities in particular categories.

In the light of the data gathered in the field, both the field elm and the European white elm should be regarded as species that favor moist, especially riparian sites. Admittedly, in both cases, a majority of the resources are located on fertile sites with non-riparian, fresh 
soils, principally at stands of potential oak-hornbeam forests, but this mainly follows from the generally bigger area of such stands. Considering the number of elm localities per area unit of a given site type, riparian forests predominate in the case of both elm species.

An analysis of the respective data (Tables 4, 5 and 7 and Figures 4 and 5) shows that in the case of the field elm, compared to the white elm, a slight shift in habitat preferences towards dry areas is occurring. Both species are often found near rivers, streams, and flow water reservoirs, but the field elm is more frequent on microsites located slightly higher than the average area of the upper, sporadically flooded plain within the river valley. Those are small elevations, dykes, and levees. It is worth noting here that elms from sites located on levees, although they come from the seeding of trees growing on a floodplain (riparian) terrace, grow on fresh rather than moist soils. The differences between the two species regard especially sites connected with major rivers, where usually field elms grow at a slightly bigger distance from the main bed, frequently beyond the levee.

\subsection{Individual Elm Species Importance in Today's Forest Communities}

Opinions that $U$. laevis is a species that is best adapted to riparian conditions have been voiced for instance by Napierała-Filipiak et al. [13], Venturas et al. [18], Richens [21], and Danielewicz [51]. However, according to phytosociological and floristic literature, the main species of the Central and West European alluvial forest, and generally of the forests in lowland Poland, should be U. minor, regarded as the most important 'forest stand building' species $[8,42,52]$. As indicated by our earlier studies [14], that is not currently reflected in Polish forests. In the examined region, this elm species is also currently rare and has lost its dominating position in the elm resources in Poland to $U$. laevis.

\subsection{Factors, That May Be Responsible for the Current State of Elms Populations}

The current state elm resources may be explained by a long-time pressure from DED and an increased susceptibility to the disease by the field elm. However, the pressure created by DED does not account for the differences in site preferences. In this context, the original domination of $U$. minor over $U$. laevis, particularly in riparian communities, may lead to certain doubts. The field elm tolerates being flooded for a long time quite well and it occurs in alluvial forests, which is attested to by numerous studies, including our own. However, Martínez-Arias et al. [53] drew attention to the fact that the ability to put up with being flooded with water for a long time is not the same in the case of all specimens. On the other hand, $U$. minor is a species more universal than $U$. laevis (a broad range of sites at which it grows reasonably well) and grows on drier land more often than the other European elms. In Ukraine, but also in Spain, it can be found mainly beyond the reach of flood water $[18,30]$. Why is it then that in Poland it gained an advantage in alluvial forests over the white elm, which is better adapted to such conditions? There may be several reasons for this. In the past, in Europe, elms used to be trees of much importance to humans (fodder; vine supports; various technical applications, including strategic ones, due to the fact that its wood is difficult to split), so they were artificially propagated and cultivated. Most probably, it was the same on Poland, for all of the abovementioned reasons. At present, Poland is not known for its vineyards, but in the past, especially in the early medieval times, many attempts were made to grow vine, because of the demand for Communion wine. Together with vine seedlings brought from the south of our continent, southern varieties of the field elm are also likely to have been imported. This is quite probable, because throughout Europe, elm varieties traveled together with vine $[7,54]$. The specimens that were brought and propagated may have numerically and genetically boosted the native resources of the tree. Because of the narrower sapwood and small root swellings, the wood of the field elm was regarded as more valuable than that of the European white elm. Where elms were cultivated for wood, they were mainly $U$. minor specimens. This may have contributed to a further spread of the species. For a very long time now, fertile alluvial forests have been regarded as very attractive for agriculture, and thus, very early on, they started to be used for various types of cultivation. This was 
connected with a decline in typically riparian elms, definitely including $U$. laevis. Field elms that grew along the edges of a river valley [30] had a higher chance of survival. From frequently occupied higher locations, they were able to relatively well seed into the river valley that was being transformed by floods and humans. In this way, they were becoming part of riparian forests that were reviving at some places. The third aspect is the field elm's exceptional ability to survive at a given location thanks to root sprouts. The significant role of sprouts in the regeneration of the wych elm population has been described for instance by Peterken and Mountford [55], Oheimb and Brunet [56], and Nielsen and Kjaer [16]. This is a species that produces sprouts mainly from trunks, and very seldom from roots. In four out of the five evaluated older forest stands with the dominating $U$. minor, under the canopy were rather numerous field elms of $0.3-2.0 \mathrm{~m}$, and sometimes $3.0 \mathrm{~m}$ in height. The fifth, small stand, of about 50 years of age, was very dense, and the subsoil, because of strong shadowing, was devoid of vegetation. In the first four forest stands, on one square meter, there were usually from several to a dozen or so specimens of the above-mentioned young field elms, which amounts up to several tens of thousands of trees when calculated per hectare. It is highly likely that most of them were not seedlings, but a vegetatively produced young generation originating from already non-existing representatives of the field elm. A very numerous $(160,000$ trees/ha) renewal of $U$. minor in forest stands in the southern Czech Republic has been reported by, for instance, Modry et al. [57]. In our study, we did not see such a numerous young generation in any of the 137 stands with the dominating $U$. laevis. Only in the case of three locations did the number of the young generation specimens calculated per hectare exceed 10,000. The big role of vegetative reproduction of the field elm is indicated by its genetic diversity, which is lower than that of the wych elm [19], and the example of $U$. minor varieties that were vegetatively reproducing for centuries-the 'English elm' and the 'Atina' variety [6,7].

\subsection{Ability to Overestimate the Number of $U$. minor in Floristic Researches}

Multiple field elms quite frequently grow under a canopy of older European white elms. A significant part of them likely originates from root sprouts of trees of various ages, whose original aboveground parts died a long time ago. The reason for the death of the aboveground section of the above-mentioned trees may have been DED or damage to a major part of their root system by water stagnating after a flood. Frequently, it is likely to have been the result of both factors. Such a damaged root system is unable to keep alive a large tree, but is quite sufficient for small root sprouts. In connection with a frequent situation where young field elms grow under the canopy of older European white elms, it cannot be ruled out that some florist and phytosociological studies overestimate the share of the field elm in the examined communities. This is not only about a smaller genetic diversity of a vegetatively reproduced population of the species [15], but about incorrect allocation to it of older elms of other species, especially Ulmus laevis. This may occur where the lowest live shoots of older trees are located several or more meters above the ground. The leaf asymmetry characteristic of $U$. laevis in the lower, unlit parts of the corona is often not clearly distinguishable. Where a young generation of trees is dominated by $U$. minor, it is easy to assume that the same is true in the upper floor.

\subsection{Relationship between the Type of Habitat and DED Symptoms}

We would like to examine the difficult problem of DED, especially the amount of damage caused by this disease, in a separate article based on the findings of our currently conducted studies. This article only presents data on DED related to the main issue discussed in it. They suggest no relationship between the type of habitat and the number of elm localities with DED symptoms.

\subsection{Suggestions for Silviculture}

It seems that specific site requirements of individual elms and their variable resistance to DED should be taken into account in the cultivation strategy for the trees. The fact that 
DED is found in all parts of the studied area [14] and on representatives of all species indicates that such activities should be done with extreme caution. According to Menkis et al. [37], timely removal of infected trees is an efficient measure in the fight against DED (at least in the case of $U$. glabra). As regards the other two elm species, according to the authors of this article, no steps should be taken, at least at the present moment, against the domination of $U$. laevis. This is a native species which is suitable-perhaps even the most suitable - for riparian sites, as suggested by our as well as some earlier studies $[13,18,21,51]$. $U$. minor should be regarded as a valuable biocenotic admixture and a basis for any future restitution of the tree. Where the species co-exists with $U$. laevis, usually this elm takes on itself the entire burden related to the possible disease [13,49]. Affected specimens should be removed and healthy ones supported during sanitation felling, irrespective of their social position-this also applies to root sprouts. It seems that the share of elms in European forests should be increased gradually. However, because of considerable prevalence of DED, it should not exceed several percent.

\section{Conclusions}

All of the examined elms can grow in a broad spectrum of fertility and moisture conditions. However, they are definitely associated with habitats that are fertile or very fertile and moist. The preference for moist habitats is the most evident in the case of $U$. laevis and the least evident in the case of $U$. glabra. U. minor is slightly more likely (than $U$. laevis) to grow in drier and less frequently flooded locations.

The similarities in respect of favored sites indicate that the European white elm and the field elm may mutually replace one another in spontaneously forming plant arrangements on riparian land in conditions created by environmental changes of various type.

The similarities in respect of sites of European white elm and the field elm indicate that these species may mutually replace one another in spontaneously forming plant arrangements on riparian land in conditions created by environmental changes of various types.

The predominant species of elm in the studied area is currently $U$. laevis, a species which until recently was cultivated in forests less frequently. It cannot be ruled out that in the past this elm lost part of its localities to the field elm as a result of a centuries-long human interference with typically riparian sites and cultivation preference for the other species.

In the examined area, the field elm is clearly on the decrease, mainly due to the longterm presence of Dutch elm disease. In many cases, however, it has been replaced by the European white elm, which means that the total elm resources in the studied area have not been reduced during the last 40 years. The resources are not significant-the actual area occupied by trees of this genus amounts to less than $0.3 \%$ of the forested area.

U. glabra is the rarest species in the examined area and it evidently prefers (favors) positions on slopes.

In comparison with the optimum conditions, the reduction in the elm resources applies to the number of trees at individual localities rather than to the number of localities themselves.

Author Contributions: Conceptualization, A.N.-F., M.F., and J.J.-J.; methodology, A.N.-F. and M.F.; software, A.N.-F., M.F., and J.J.-J.; validation, M.F. and J.J.-J.; formal analysis, A.N.-F. and M.F.; investigation, A.N.-F., M.F., and J.J.-J.; resources, A.N.-F.; data curation, A.N.-F., M.F., and J.J.-J.; writing - original draft preparation, A.N.-F. and M.F.; writing—review and editing, A.N.-F. and M.F.; visualization, A.N.-F.; supervision, A.N.-F.; project administration, A.N.-F.; funding acquisition, A.N.-F. All authors have read and agreed to the published version of the manuscript.

Funding: This study was supported by the National Science Centre, Poland, grant No. 2011/01/B/ NZ9/02883 "Assessment of the present population size, distribution, and condition of elms (Ulmus spp.) in Poland," the Institute of Dendrology, Polish Academy of Sciences, Kórnik, Poland, and the Wrocław University of Environmental and Life Sciences, The Faculty of Environmental Engineering and Geodesy, Institute of Landscape Architecture, Wrocław, Poland. 
Institutional Review Board Statement: Not applicable.

Informed Consent Statement: Not applicable.

Data Availability Statement: The data presented in this study are available on request from the corresponding author.

Conflicts of Interest: The authors declare no conflict of interest. The funders had no role in the design of the study; in the collection, analyses, or interpretation of data; in the writing of the manuscript, or in the decision to publish the results.

\section{References}

1. Boratyńska, K.; Sękiewicz, M.; Boratyński, A. Morfologia, systematyka, zmienność i rozmieszczenie geograficzne. [Morphology, systematics, variability and geographical distribution]. In Wiazy [Elms]; Bugała, W., Boratyński, A., Iszkuło, G., Eds.; Bogucki Wydawnictwo Naukowe: Poznań, Poland, 2015; pp. 24-52.

2. Filipiak, M.; Napierała-Filipiak, A. Zarys ekologii [Outline of ecology]. In Wiazy [Elms]; Bugała, W., Boratyński, A., Iszkuło, G., Eds.; Bogucki Wydawnictwo Naukowe: Poznań, Poland, 2015; pp. 133-181.

3. Brasier, C.M. Ophiostoma novo-ulmi sp. nov., causative agent of the current Dutch elm disease pandemics. Mycopathologia 1991, 115, 151-161. [CrossRef]

4. Collin, E.; Rondouin, M.; Joyeau, C.; Matz, S.; Raimbault, P.; Harvengt, L.; Bilger, I.; Guibert, M. Conservation and use of elm genetic resources in France: Results and perspectives. iForest-Biogeosci. For. 2020, 13, 41-47. [CrossRef]

5. $\quad$ Łakomy, P.; Kwaśna, H.; Kuźmiński, R.; Napierała-Filipiak, A.; Filipiak, M.; Behnke, K.; Behnke-Borowczyk, J. Investigation of Ophiostoma population infected elms in Poland. Dendrobiology 2016, 76, 137-144. [CrossRef]

6. Martín, J.A.; Sobrino-Plata, J.; Rodríguez-Calcerrada, J.; Collada, C.; Gil, L. Breeding and scientific advances in the fight against Dutch elm disease: Will they allow the use of elms in forest restoration? New For. 2019, 50, 183-215. [CrossRef]

7. Heybroek, H.M. The elm, tree of milk and wine. iForest-Biogeosci. For. 2015, 8, 181-186. [CrossRef]

8. Jaworski, A. Hodowla Lasu. Charakterystyka Hodowlana Drzew i Krzewów Leśnych [ Silviculture, Characteristics of Forest Trees and Shrubs; PWRiL: Warszawa, Poland, 2011.

9. Mańka, K.; Sobiczewski, P.; Mańka, M.; Fiedorow, Z. Fitopatologia Leśna [Forest Pathology]; PWRiL: Warszawa, Poland, 2005.

10. Santini, A.; Faccoli, M. Dutch elm disease and elm bark beetles: A century of association. iForest-Biogeosci. For. 2015, 8, 126-134. [CrossRef]

11. Mackenthun, G.L. Elm Losses and their Causes over a 20 Year Period-A long-term Study of Ulmus in Saxony, Germany. In Proceedings of the Third International Elm Conference, Florence, Italy, 9-11 October 2013; pp. 9-11.

12. Napierała-Filipiak, A.; Filipiak, M.; Jaworek, J. Rozmieszczenie zasobów drzew z rodzaju wiąz (Ulmus spp.) w lasach Polski w świetle dokumentacji leśnej [Distribution of elms (Ulmus spp.) in Polish forests according to the forestry inventory]. Sylwan 2014, 158, 811-820.

13. Napierała-Filipiak, A.; Filipiak, M.; Łakomy, P.; Kuźmiński, R.; Gubański, J. Changes in elm (Ulmus) populations of mid-western Poland during the past 35 years. Dendrobiology 2016, 76, 145-156. [CrossRef]

14. Napierała-Filipiak, A.; Filipiak, M.; Łakomy, P. Changes in the Species Composition of Elms (Ulmus spp.) in Poland. Forests 2019, 10, 1008. [CrossRef]

15. Chudzińska, M.; Pałucka, M.; Pasławska, A.; Litkowiec, M.; Lewandowski, A.; Kozioł, C. Wyniki wstępnych badań nad zmiennością genetyczną oraz zróżnicowaniem genetycznym między populacjami wiązu górskiego (Ulmus glabra Huds.) w Polsce [Results of preliminary research on genetic variation and genetic differentiation between Wych elm populations]. (Ulmus glabra Huds.) in Poland]. Sylwan 2018, 162, 727-736. [CrossRef]

16. Nielsen, L.R.; Kjær, E.D. Fine-scale gene flow and genetic structure in a relic Ulmus laevis population at its northern range. Tree Genet Genomes 2010, 6, 643-649. [CrossRef]

17. Puerto, M.M.; García, F.M.; Mohanty, A.; Martín, J.P. Genetic diversity in relict and fragmented populations of Ulmus glabra Hudson in the Central System of the Iberian Peninsula. Forests 2017, 8, 143. [CrossRef]

18. Venturas, M.; Fuentes-Utrilla, P.; López, R.; Perea, R.; Fernández, V.; Gascó, A.; Guzmán, P.; Li, M.; Rodríguez-Calcerrada, J.; Miranda, E.; et al. Ulmus laevis in the Iberian Peninsula: A review of its ecology and conservation. iForest 2015, 8, 135-142. [CrossRef]

19. Fuentes-Utrilla, P.; Venturas, M.; Hollingsworth, P.M.; Squirrell, J.; Collada, C.; Stone, G.N.; Gil, L. Extending glacial refugia for a European tree: Genetic markers show that Iberian populations of white elm are native relicts and not introductions. Heredity 2014, 112, 105-113. [CrossRef] [PubMed]

20. Mackenthun, G.L. The role of Ulmus laevis in German floodplain landscapes. For. Syst. 2004, 13, 55-63.

21. Richens, R.H. Elm; Cambridge University Press: Cambridge, UK, 1983.

22. Heybroek, H.M. The Dutch elm breeding program. In Dutch Elm Disease Research: Cellular and MolecularApproaches; Sticklen, M.B., Sherald, J.L., Eds.; Springer: New York, NY, USA, 1993; pp. 16-25.

23. Kieliszewska-Rokicka, B. Wymiana gazowa i gospodarka wodna [Gas exchange and water relations]. In Wiazy [Elms]; Bugała, W., Boratyński, A., Iszkuło, G., Eds.; Bogucki Wydawnictwo Naukowe: Poznań, Poland, 2015; pp. 82-95. 
24. Babushkina, E.A.; Zhirnova, D.F.; Belokopytova, L.V.; Tychkov, I.I.; Vaganov, E.A.; Krutovsky, K.V. Response of Four Tree Species to Changing Climate in a Moisture-Limited Area of South Siberia. Forests 2019, 10, 999. [CrossRef]

25. Yuan, Y.; Ren, Y.; Gao, G.; Zhao, Z.; Niu, S. Intra-and interspecific interactions among pioneer trees affect forest-biomass carbon accumulation in a nutrient-deficient reclaimed coal mine spoil. Forests 2020, 11, 819. [CrossRef]

26. Kassahun, Z.; Yow, J.N.; Renninger, H.J. Diversity or Redundancy in Leaf Physiological and Anatomical Parameters in a Species Diverse, Bottomland Hardwood Forest? Forests 2020, 11, 519. [CrossRef]

27. Falkengren-Grerup, U.; Brunet, J.; Diekmann, M. Nitrogen mineralisation in deciduous forest soils in south Sweden in gradients of soil acidity and deposition. Environ. Pollut. 1998, 102, 415-420. [CrossRef]

28. Polyakova, O.; Billor, N. Impact of deciduous tree species on litterfall quality, decomposition rates and nutrient circulation in pine stands. For. Ecol. Manag. 2007, 253, 11-18. [CrossRef]

29. Li, X.; Dong, W.; Song, Y.; Wang, W.; Zhan, W. Effect of Soil Fauna on Home-Field Advantages of Litter Mass Loss and Nutrient Release in Different Temperate Broad-Leaved Forests. Forests 2019, 10, 1033. [CrossRef]

30. Pogrebniak, P. Podstawy Typologii Leśnej [Basics of Forest Typology]; PWRiL: Warszawa, Poland, 1961.

31. Mittempergher, L.; Santini, A. The history of elm breeding. For. Syst. 2004, 13, 161-177.

32. Mioduszewski, S.; Korczyk, A.F. Growth of Ulmus glabra Huds. grafts in the clone archive in Bielsk Forest District. Leśne Prace Badawcze [For. Res. Pap.] 2013, 74, 149-159. [CrossRef]

33. Piou, D.; Benest, F.; Collin, E. Est-il possible de tirer des enseignements des introductions anciennes? L'exemple de la graphiose de l'orme [Are there any lessons to be learnt from long-standing introductions of pathogens? The case of Dutch Elm Disease]. Revue Forestière Française 2018, 70, 621-637. [CrossRef]

34. Martín, J.A.; Solla, A.; Esteban, L.G.; De Palacios, P.; Gil, L. Bordered pit and ray morphology involvement in elm resistance to Ophiostoma novo-ulmi. Can. J. Bot. 2009, 39, 420-429. [CrossRef]

35. Solheim, H.; Eriksen, R.; Hietala, A.M. Dutch elm disease has currently a low incidence on wych elm in Norway. For. Path. 2011, 41, 182-188. [CrossRef]

36. Urban, J.; Dvořák, M. Sap flow-based quantitative indication of progression of Dutch elm disease after inoculation with Ophiostoma novo-ulmi. Trees 2014, 28, 1599-1605. [CrossRef]

37. Menkis, A.; Östbrant, I.L.; Wågström, K.; Vasaitis, R. Dutch elm disease on the island of Gotland: Monitoring disease vector and combat measures. Scand. J. For. Res. 2016, 31, 237-241. [CrossRef]

38. Flynn, L.E.; Mitchell, F.J.G. Comparison of a recent elm decline with the mid-Holocene Elm Decline. Veg. His. Archaeob. 2018, 1-8. [CrossRef]

39. Martín, J.A.; Solla, A.; Ruiz-Villar, M.; Gil, L. Vessel length and conductivity of Ulmus branches: Ontogenetic changes and relation to resistance to Dutch elm disease. Trees 2013, 27, 1239-1248. [CrossRef]

40. Gong, J.; Zhang, Z.; Zhang, C.; Zhang, J.; Ran, A. Ecophysiological responses of three tree species to a high-altitude environment in the Southeastern Tibetan Plateau. Forests 2018, 9, 48. [CrossRef]

41. Sepúlveda, P.; Johnstone, D.M. A novel way of assessing plant vitality in urban trees. Forests 2019, 10, 2. [CrossRef]

42. Bohn, U.; Gollub, G.; Hettwer, C.; Neuhäuslová, Z.; Raus, T.; Schlüter, H.; Weber, H. Karte der natürlichen Vegetation Europas Map of the Natural Vegetation of Europe Maßstab/Scale 1: 2500 000; Bundesamt für Naturschutz (BfN)/Federal Agency for Nature Conservation: Bonn, Germany, 2004.

43. Matuszkiewicz, J.M. Rola wiązów w zespołach roślinnych Polski [The role of the elms in plant associations in Poland]. In Wiazy [Elms]; Bugała, W., Boratyński, A., Iszkuło, G., Eds.; Bogucki Wydawnictwo Naukowe: Poznań, Poland, 2015; pp. 181-235.

44. Forest Data Bank. Available online: https://www.bdl.lasy.gov.pl/portal/ (accessed on 5 October 2020).

45. Hartmann, G.; Nienhaus, F.; Butin, H. Farbatlas Waldschäden: Diagnose von Baumkrankheiten; Eugen Ulmer KG: Stuttgart, Germany, 2007.

46. Snedecor, G.W.; Cochran, W.G. Statistical Methods, 6th ed.; The Iowa State University Press: Ames, IA, USA, 1976; pp. 327-329.

47. Milewski, W. Lasy w Polsce 2017; Centrum Informacyjne Lasów Państwowych: Warszawa, Poland, 2017. Available online: http: / / www.lasy.gov.pl/pl/informacje/publikacje/do-poczytania/lasy-w-polsce-1/lasy-w-polsce-2017-pl-internet.pdf (accessed on 30 December 2017).

48. Martín-Benito, D.; García-Vallejo, M.C.; Pajares, J.A.; López, D. Triterpenes in elms in Spain. Can. J. For. Res. 2005, 35, 199-205. [CrossRef]

49. Filipiak, M.; Napierała-Filipiak, A.; Banacki, J. Wiąz górski (Ulmus glabra Huds.), wiąz szypułkowy (U. laevis Pall.) i wiąz polny (U. minor Mill.) na terenie Bałtyckiej Krainy Przyrodniczo-Leśnej [Wych elm (Ulmus glabra Huds.), European white elm (U. laevis Pall.) and field elm (U. minor Mill.) in the Bltic Natural Forest Region]. Acta Sci. Pol. Silv. Colendar. Ratio Ind. Lignar. 2018, 17, 333-344.

50. Głaz, J. Wiaz w Lasach Państwowych. [Elm in the State Forests]. Sylwan 1986, 130, $23-33$.

51. Danielewicz, W. Ekologiczne Uwarunkowania Zasięgów drzew i Krzewów na Aluwialnych Obszarach doliny Odry. [Ecological Determinants of the Range of Trees and Shrubs in the Alluvial Areas of the Oder Valley]; Wydawnictwo Uniwersytetu Przyrodniczego: Poznan, Poland, 2008.

52. Kosiński, P. Rozmieszczenie Oraz Warunki Występowania Drzew i Krzewów w Polskiej części Sudetów Wschodnich [Distribution and Conditions of Occurrence of Trees and Shrubs in the Polish Part of the Eastern Sudety Mts]; Acta Botanica Silesiaca, Monographiae 1, Bogucki Wydawnictwo Naukowe: Poznań, Poland, 2007. 
53. Martínez-Arias, C.; Sobrino-Plata, J.; Macaya-Sanz, D.; Aguirre, N.M.; Collada, C.; Gil, L.; Martín, J.A.; Rodríguez-Calcerrada, J. Changes in plant function and root mycobiome caused by flood and drought in a riparian tree. Tree Phys. 2020, 40, 886-903. [CrossRef]

54. Wawro, E. Winnice w Polsce [Vineyards in Poland]; Multico: Warszawa, Poland, 2015.

55. Peterken, G.F.; Mountford, E.P. Long-term change in an unmanaged population of elm subjected to Dutch elm disease. J. Ecol. 1998, 86, 205-218. [CrossRef]

56. Oheimb, G.; Brunet, J. Long-term vegetation changes in a south Swedish deciduous forest. Acta Oecol. 2007, 31, 229-242. [CrossRef]

57. Modrý, M.; Hubený, D.; Rejšek, K. Differential response of naturally regenerated European shade tolerant tree species to soil type and light availability. For. Ecol. Manag. 2004, 188, 185-195. [CrossRef] 